\title{
Assessment of Surface Water Contamination from Coalbed Methane Fracturing-Derived Volatile Contaminants in Sullivan County, Indiana, USA
}

\author{
Nicholas Meszaros \\ DePauw University \\ Bikram Subedi \\ Murray State University, bsubedi@murraystate.edu \\ Tristan Stamets \\ DePauw University \\ Naima Shifa \\ Depauw
}

Follow this and additional works at: https://digitalcommons.murraystate.edu/faculty

Part of the Analytical Chemistry Commons, Environmental Chemistry Commons, Environmental Health and Protection Commons, Environmental Indicators and Impact Assessment Commons, and the Environmental Monitoring Commons

\section{Recommended Citation}

Meszaros, Nicholas; Subedi, Bikram; Stamets, Tristan; and Shifa, Naima, "Assessment of Surface Water Contamination from Coalbed Methane Fracturing-Derived Volatile Contaminants in Sullivan County, Indiana, USA" (2017). Faculty \& Staff Research and Creative Activity. 14.

https://digitalcommons.murraystate.edu/faculty/14

This Journal Article is brought to you for free and open access by Murray State's Digital Commons. It has been accepted for inclusion in Faculty \& Staff Research and Creative Activity by an authorized administrator of Murray State's Digital Commons. For more information, please contact msu.digitalcommons@murraystate.edu. 


\title{
Assessment of Surface Water Contamination from Coalbed Methane Fracturing-Derived Volatile Contaminants in Sullivan County, Indiana, USA
}

\author{
Nicholas Meszaros $^{1} \cdot$ Bikram Subedi $^{2,3} \cdot$ Tristan Stamets $^{1} \cdot$ Naima Shifa $^{4}$
}

Received: 20 May 2017 / Accepted: 4 July 2017

(C) Springer Science+Business Media, LLC 2017

\begin{abstract}
There is a growing concern over the contamination of surface water and the associated environmental and public health consequences from the recent proliferation of hydraulic fracturing in the USA. Petroleum hydrocarbon-derived contaminants of concern [benzene, toluene, ethylbenzene, and xylenes (BTEX)] and various dissolved cations and anions were spatially determined in surface waters around 15 coalbed methane fracking wells in Sullivan County, IN, USA. At least one BTEX compound was detected in $69 \%$ of sampling sites $(n=13)$ and $23 \%$ of sampling sites were found to be contaminated with all of the BTEX compounds. Toluene was the most common BTEX compound detected across all sampling sites, both upstream and downstream from coalbed methane fracking wells. The average concentration of toluene at a reservoir and its outlet nearby the fracking wells was $\sim 2 \times$ higher than other downstream sites. However, one of the upstream sites was found to be contaminated with BTEX at similar concentrations as in a reservoir site nearby the fracking well. Calcium ( $\sim 60 \mathrm{ppm})$ and sulfates $(\sim 175 \mathrm{ppm})$ were the dominant cations and anions, respectively, in surface water
\end{abstract}

Nicholas Meszaros

nmeszaros_2018@depauw.edu

$\triangle$ Bikram Subedi

bsubedi@murraystate.edu

1 Department of Geosciences, DePauw University, Greencastle, IN 46135, USA

2 Department of Chemistry, Wabash College, Crawfordsville, IN 47933, USA

3 Department of Chemistry, Murray State University, Murray, KY 42071, USA

4 Department of Mathematics, DePauw University, Greencastle, IN 46135, USA around the fracking sites. This study represents the first report of BTEX contamination in surface water from coalbed methane hydraulic fracturing wells.

Keywords Coalbed methane $\cdot$ Hydraulic fracturing BTEX $\cdot$ Dissolved ions · Indiana

Recent technological developments in hydraulic fracturing made the cost-effective extraction of natural gas from less permeable shale possible. The number of hydraulically fractured wells in the USA increased by $91 \%$ to $~ 300,000$ (from 2000 to 2015), which accounts for $67 \%$ of the total natural gas production (Perrin and Cook 2016). Typically, $10,000-15,000 \mathrm{~m}^{3}$ of water containing additives including biocides, breakers/oxidizers, corrosion inhibitors, iron controllers, oxygen scavengers, and scale inhibitors are used in horizontal fracking sites in the USA (Gallegos and Varela 2015). Up to $80 \%$ of injected water returns to the surface as flowback water that contains high levels of organics having a wide-range of physicochemical properties including petroleum-derived hydrocarbons, industrial solvents, and surfactants (Ferrar et al. 2013; Gregory et al. 2011). Additionally, flowback water is also known to contain radioactive materials, heavy metals, and halide salts (Carpenter 2016; Finkel 2015).

Petroleum-derived hydrocarbons such as benzene, toluene, ethylbenzene, and xylenes (BTEX) were reported up to $13,71,9.0$, and $39 \mathrm{ppb}$ levels, respectively, in wastewater effluents that treat flowback water in Pennsylvania (Ferrar et al. 2013). Haluszczak et al. (2013) reported that flowback water from several western and central Pennsylvanian fracking wells had chloride, sodium, calcium, and potassium concentrations of $98,000,36,400,11,200$, and $281 \mathrm{ppm}$ levels respectively, classifying the flowback water 
as a brine (Haluszczak et al. 2013). Proper treatment and/ or disposal of large-volume waste from fracturing wells is a daunting challenge in the USA (Getzinger et al. 2015; Warner et al. 2013). BTEX are prone to leach from soils into groundwater owing to their relatively high water solubility and low $K_{\text {ow }}$ values, therefore resulting in the contamination of drinking water (Peng et al. 2015).

BTEX are listed as priority pollutants by the United States Environmental Protection Agency (USEPA) under the Clean Water Act (USEPA 2012). Surface water contamination of BTEX can pose human health risks (Carpenter 2016; Parker et al. 2014) as well as adverse ecological consequences such as physiological alterations in fish embryos (Menidia beryllina) (Adeyemo et al. 2015) and decreased chlorophyll content in an algae (Euglena gracilis) (Peng et al. 2015).

Indiana is not traditionally known for hydraulic fracturing. However, with the passing of Senate Bill 71 by the Indiana Legislature in 2011, coalbed methane hydraulic fracturing is allowed in "commercially saleable" coal seams (Greenwell and Keller 2013). This study examines the potential surface water contamination from 15 small coalbed methane fracking wells in operation along Turtle Creek in Sullivan County, Indiana, USA.

Typically, the optimum production of natural gases from coalbed methane hydraulic fracturing wells may occur several months after the removal of a sufficient amount of pore water from the coal matrix (Moore 2012). Therefore, coalbed methane hydraulically fractured wells can pose a risk towards contaminating surface water for a longer period than from conventional oil and gas wells. To our knowledge, there are no reports of BTEX contamination in surface water from coalbed methane hydraulic fracturing wells. In this study, the spatial distribution of the occurrence of BTEX in surface waters was determined around coalbed methane hydraulic fracturing wells in Sullivan County, Indiana, USA. The spatial distribution of major dissolved ions (cations: lithium, sodium, potassium, magnesium, calcium, and ammonium; anions: fluoride, chloride, bromide, nitrite, nitrate, and sulfate) were also determined.

\section{Materials and Methods}

Triplicate surface water samples ( $250 \mathrm{~mL}$, grab samples) were collected from the central flow of 13 upstream and downstream sites of coalbed methane hydraulic fracturing wells $(n=15)$ located along Turtle Creek in Sullivan County, Indiana, USA on October 11th and November 8th, 2015 (Fig. 1). There was a total of six samples from all sampling sites while only two samples were collected from LTC_A. The sampling sites were chosen based on the proximity to an outflow or inflow of a subwatershed, the confluence of tributaries, and site accessibility. Samples were collected in acid washed Nalgene bottles, stored in ice, transported back to DePauw University, and stored at $4^{\circ} \mathrm{C}$ until further analysis.

All chemicals (purity: $\geq 99 \%$ ) were purchased from commercial vendors. Analytes (benzene, toluene, ethylbenzene, xylenes) and hexane were purchased from Sigma-Aldrich (St. Louis, MO, USA). An internal standard toluene- $\mathrm{D}_{8}$ was purchased from Sigma-Aldrich. All standard stock solutions were prepared in hexane and stored in a refrigerator. The working solutions were prepared in hexane as needed. Nylon filters $(30 \mathrm{~mm}, 0.45 \mu \mathrm{m})$ and magnetic stirrers were purchased from Fisherbrand (Pittsburg, PA, USA). Seven Anion Standard II solution and Six Cation Standard II solution were purchased from Dionex (Sunnyvale, CA, USA).

BTEX compounds were analyzed using an Agilent 6850 Series GC System and Agilent 5973 Network Mass Spectrometer. Samples were prepared for analysis by filling $5 \mathrm{~mL}$ glass vials with $4.0 \mathrm{~mL}$ of water sample filtered through $30 \mathrm{~mm} \times 0.45 \mu \mathrm{m}$ nylon filters, $0.9 \mathrm{~mL}$ of hexane, and $0.1 \mathrm{~mL}$ of an internal standard (toluene- $\mathrm{d}_{8}$ ). Vials were shaken manually for $1 \mathrm{~min}$ followed by continuous stirring for $5 \mathrm{~min}$. The samples were allowed to separate solvent layers for 5 min and then $0.2 \mu \mathrm{L}$ of the hexane extract was injected into the GC/MS analysis. BTEX were analyzed using an Agilent HP-5 column $(30 \mathrm{~m} \times 0.25 \mathrm{~mm}$ i.d. $\times 0.25 \mu \mathrm{m})$ at an initial oven temperature of $40^{\circ} \mathrm{C}$, held for $1 \mathrm{~min}$, ramped to $200^{\circ} \mathrm{C}$ at $15^{\circ} \mathrm{C} / \mathrm{min}$, and held for an additional minute. Injection port and detector were held at $280^{\circ} \mathrm{C}$ while MS quad and MS source were maintained at $150^{\circ} \mathrm{C}$ and $230^{\circ} \mathrm{C}$, respectively.

Dissolved ions were analyzed using a Dionex ICS-2000 Ion Chromatography System using Dionex IonPac AS18 $4 \times 250 \mathrm{~mm}$ and CS16 $5 \times 250 \mathrm{~mm}$ columns guarded with a Dionex CG16 $5 \times 50 \mathrm{~mm}$ column. Cations were separated using $30 \mathrm{mmol}$ methansulfonic acid (suppressor current of $89 \mathrm{~mA}$ for $40 \mathrm{~min}$ ) whereas anions were separated using $24 \mathrm{mmol} \mathrm{KOH}$ (suppressor current of $60 \mathrm{~mA}$ for $15 \mathrm{~min}$ ) in an isocratic eluent mode. The system was flushed with $250 \mu \mathrm{L}$ of deionized water and primed with an additional $250 \mu \mathrm{L}$ of deionized water prior to sample injection. Samples were filtered through $0.45 \mu \mathrm{m}$ nylon filters and injected $(20 \mu \mathrm{L})$ for the analysis at a constant temperature of $40^{\circ} \mathrm{C}$.

Internal standard method of quantification $(7.3 \mathrm{ppm}$ toluene- $\mathrm{d}_{8}$ ) with a seven point calibration curve was used for the quantification of BTEX. The concentration of analytes in calibration solutions ranged in concentration from 0.05 to $16.5 \mathrm{ppm}$. The coefficient of determination from a linear calibration curve was $\leq 0.99$. The identification of BTEX peaks in samples were based on their retention time $( \pm 0.05 \mathrm{~min}$ ), two major $\mathrm{m} / \mathrm{z}$ ions (benzene: $\mathrm{m} / \mathrm{z} 78$ and 52; toluene: $\mathrm{m} / \mathrm{z} 91$ and 65; ethylbenzene: $\mathrm{m} / \mathrm{z} 91$ and 106; and xylenes: $\mathrm{m} / \mathrm{z} 91$ and 106), and the ratio of two major $\mathrm{m} / \mathrm{z}$ ions in selected ion monitoring (SIM) mode. Major cations 


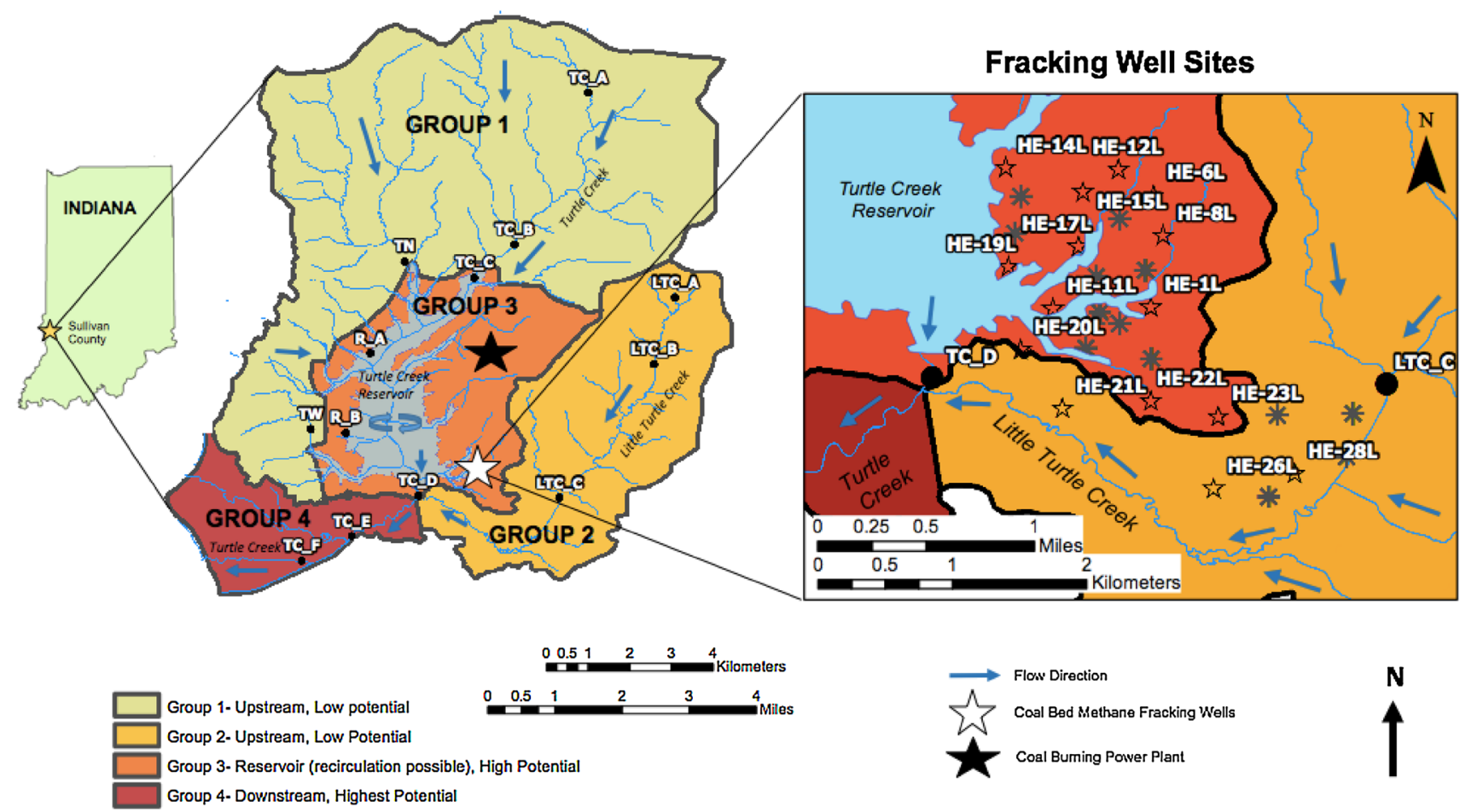

Fig. 1 Sampling sites. Blue arrows indicate direction of water flow. The white star localizes all 15 coalbed methane fracturing wells, and the black star localizes a coal-burning power plant. Group 1 represents upstream sites of fracturing wells and the headwaters of Turtle Creek (TC), and includes sampling sites TC_A, TC_B, TN, and TW. Turtle Creek flows into Turtle Creek Reservoir (major part of Group 3). Little Turtle Creek (LTC), a major tributary of Turtle Creek, was sampled at LTC_A, LTC_B, and LTC_C, which are classified as Group 2 upstream sites with low probability for contamination from the fracking wells. The headwaters of Little Turtle Creek also originate within the Group 2 boundary. Group 3 is defined as Turtle Creek Reservoir and was sampled at a mouth of Turtle Creek (i.e. TC_C)

(lithium, sodium, potassium, ammonium, magnesium, and calcium) and anions (fluoride, chloride, bromide, nitrite, nitrate, and sulfate) were quantified using Six Cation Standard II and Seven Anion Standard II solutions, respectively.

A method blank fortified with an internal standard (7.28 ppm toluene- $\mathrm{d}_{8}$ ) was prepared and analyzed in every batch of BTEX analyses following the procedures described above. No carry over was observed during chromatographic separations. However, select samples were observed to have benzene contamination and were corrected. Samples and a method blank were bracketed by a continuous calibration verification (CCV: mid-point calibration) solution in each batch of sample analyses. The BTEX concentrations were found to be within $\pm 10 \%$ in the CCV standard solution. Limit of quantification (LOQ) for each analyte was determined as a concentration corresponding to $\mathrm{S} / \mathrm{N}$ ratio of 10 ; LOQs ranged from $0.05 \mathrm{ppm}$ (toluene) to $0.10 \mathrm{ppm}$ (benzene). For statistical analysis, <LOQ analytical data were replaced by $1 / 2 \mathrm{LOQ}$ values. and two shoreline locations of the reservoir (i.e. $\mathrm{R} \_A$ and $\mathrm{R} \_\mathrm{B}$ ). The reservoir outflow was sampled at TC_D. Turtle Creek was sampled downstream, after the reservoir outflow confluence with Little Turtle Creek, at TC_E and TC_F, and comprises Group 4, where the culmination of surface water contamination should be expressed. The inset on the right shows the location of the coalbed methane fracking sites on a larger scale [Source: Google Earth satellite Imagery and Indiana Department of Natural Resources (IDNR)]. Clear stars represent fracking well pad locations (along with their well numbers) and gray asterisks represent the location of additional gas exploration well pads that were not identified as being active fracking wells by the IDNR at the time of sample collection

A method blank (deionized water filtered through $0.45 \mu \mathrm{m}$ nylon filter) was prepared and analyzed in each batch of analyses of cations and anions. No cations were detected $>0.81 \mathrm{ppm}$ and no anions were detected $>0.15 \mathrm{ppm}$ in the method blank, except for nitrite at a concentration of $0.25 \mathrm{ppm}$. Consequently, all data points were blank corrected. Every five samples were bracketed by a calibration standard solution to determine whether the retention time had drifted. No significant drift in retention time $( \pm 0.05 \mathrm{~min})$ was observed for either cations or anions.

The analytical method capable of determination of BTEX in surface water was validated through a triplicate spiking and recovery experiment. The triplicate water samples were spiked with BTEX $(0.9 \mathrm{~mL}$ of $1.24-1.65 \mathrm{ppm}$ in hexane) and internal standard $(0.1 \mathrm{~mL}$ of $7.28 \mathrm{ppm}$ toluene$\mathrm{d}_{8}$ in hexane), mixed well, and allowed to separate solvent layers. $0.2 \mu \mathrm{L}$ of the hexane extract was injected into the GC/MS for analysis. A method blank was prepared and 
analyzed as discussed above. The spiking recoveries and the relative standard deviations for triplicate analysis were $90.3 \pm 1.8 \%, 104.8 \pm 1.1 \%, 102.4 \pm 2.1 \%$, and $101.0 \pm 2.1 \%$, respectively, for benzene, toluene, ethylbenzene, and xylenes.

\section{Results and Discussion}

All analytes were detected at a reservoir site nearby the fracking wells (R_B) and at the outlet of reservoir (TC_D) (Table 1; Fig. 2). However, no analytes were detected in
Table 1 Concentration of BTEX in surface water samples $(\mathrm{n}=6)^{\mathrm{a}}$ around fracking wells in Sullivan County, Indiana

\begin{tabular}{lllllll}
\hline Group & Sites & GPS coordinates & \multicolumn{2}{l}{ Range of concentration of analytes (ppb) } \\
\cline { 4 - 7 } & & & Benzene & Toluene & Ethylbenzene & Xylenes \\
\hline 1 & TC_A & $87^{\circ} 29^{\prime} 19.38^{\prime \prime} \mathrm{W}, 39^{\circ} 07^{\prime} 42.01^{\prime \prime} \mathrm{N}$ & ND-135 & ND-183 & ND-175 & ND-175 \\
1 & TC_B & $87^{\circ} 30^{\prime} 16.50^{\prime \prime} \mathrm{W}, 39^{\circ} 05^{\prime} 44.60^{\prime \prime} \mathrm{N}$ & ND-LOQ & ND-97.5 & ND-95.0 & ND-95.0 \\
1 & TN & $87^{\circ} 31^{\prime} 41.74^{\prime \prime} \mathrm{W}, 39^{\circ} 05^{\prime} 31.37^{\prime \prime} \mathrm{N}$ & ND-LOQ & ND-65.0 & ND-LOQ & ND-LOQ \\
1 & TW & $87^{\circ} 32^{\prime} 54.43^{\prime \prime} \mathrm{W}, 39^{\circ} 03^{\prime} 21.99^{\prime \prime} \mathrm{N}$ & ND-LOQ & ND-67.5 & ND-LOQ & ND-LOQ \\
2 & LTC_A & $87^{\circ} 27^{\prime} 59.45^{\prime \prime} \mathrm{W}, 39^{\circ} 05^{\prime} 04.39^{\prime \prime} \mathrm{N}$ & LOQ & LOQ & LOQ & LOQ \\
2 & LTC_B & $87^{\circ} 28^{\prime} 28.23^{\prime \prime} \mathrm{W}, 39^{\circ} 04^{\prime} 11.99^{\prime \prime} \mathrm{N}$ & ND-LOQ & ND-LOQ & ND-LOQ & ND-LOQ \\
2 & LTC_C & $87^{\circ} 29^{\prime} 41.83^{\prime \prime} \mathrm{W}, 39^{\circ} 02^{\prime} 28.44^{\prime \prime} \mathrm{N}$ & ND-LOQ & ND-60.0 & ND-LOQ & ND-LOQ \\
3 & TC_C & $87^{\circ} 30^{\prime} 47.57^{\prime \prime} \mathrm{W}, 39^{\circ} 05^{\prime} 18.70^{\prime \prime} \mathrm{N}$ & ND-LOQ & ND-50.0 & ND-LOQ & ND-LOQ \\
3 & R_A & $87^{\circ} 32^{\prime} 09.40^{\prime \prime} \mathrm{W}, 39^{\circ} 04^{\prime} 26.29^{\prime \prime} \mathrm{N}$ & ND-LOQ & ND-LOQ & ND-LOQ & ND-LOQ \\
3 & R_B & $87^{\circ} 32^{\prime} 24.06^{\prime \prime} \mathrm{W}, 39^{\circ} 03^{\prime} 18.43^{\prime \prime} \mathrm{N}$ & ND-148 & ND-238 & ND-248 & ND-245 \\
4 & TC_D & $87^{\circ} 31^{\prime} 30.81^{\prime \prime} \mathrm{W}, 39^{\circ} 02^{\prime} 29.90^{\prime \prime} \mathrm{N}$ & ND-108 & ND-205 & ND-205 & ND-198 \\
4 & TC_E & $87^{\circ} 32^{\prime} 22.52^{\prime \prime} \mathrm{W}, 39^{\circ} 01^{\prime} 58.56^{\prime \prime} \mathrm{N}$ & ND-LOQ & ND-57.5 & ND-LOQ & ND-LOQ \\
4 & TC_F & $87^{\circ} 33^{\prime} 01.40^{\prime \prime} \mathrm{W}, 39^{\circ} 01^{\prime} 39.50^{\prime \prime} \mathrm{N}$ & ND-LOQ & ND-LOQ & ND-LOQ & ND-LOQ \\
\hline
\end{tabular}

$N D$ non-detects, $L O Q$ limit of quantitation, $L O Q s$ for benzene, toluene, ethylbenzene, and xylenes were $100,50,80$, and $90 \mathrm{ppb}$, respectively

${ }^{a}$ No significant differences in BTEX concentrations were found in triplicate samples from two sampling events

${ }^{\text {b}}$ Only two samples were analyzed for LTC_A

\section{BTEX Surface Water Concentrations}

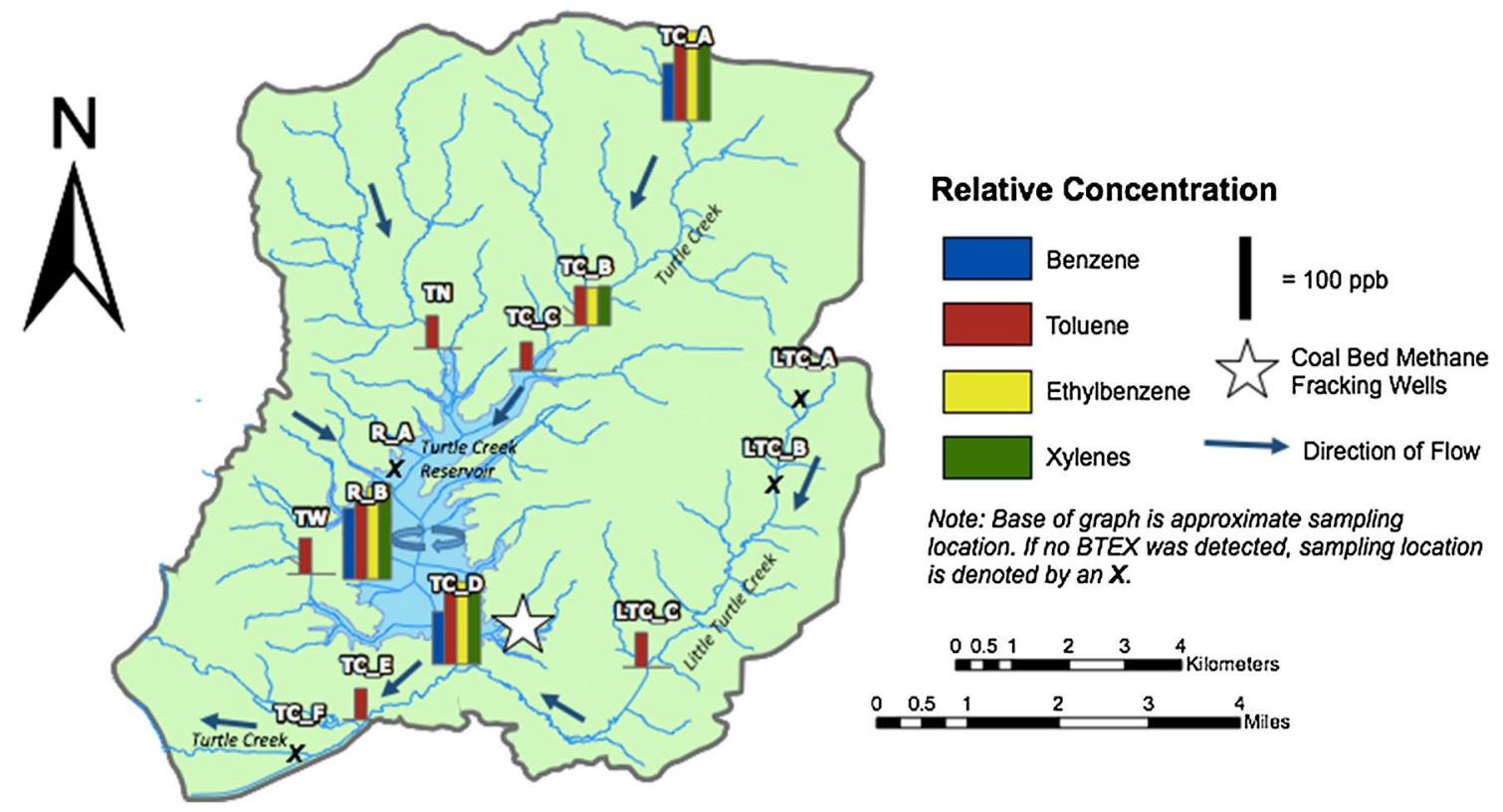

Fig. 2 Spatial distribution of average concentrations of BTEX compounds in study sites. Sample sites with non-detects are denoted by an X. Concentration ranges and GPS coordinates are provided in Table 1 
tributary sites and the farthest downstream site except toluene. Toluene was detected in $71 \%$ of sampling sites $(n=13)$ upstream as well as downstream of 15 fracking wells in Sullivan County, Indiana. The average concentration of toluene at reservoir site (R_B) and reservoir outlet site (TC_D) was $\sim 2 \times$ higher than other downstream sites and the tributary sites. The upstream site (TC_A) was found to be contaminated with BTEX at similar concentrations as in a reservoir site nearby the fracking wells (Table 1). The analyte's potential of atmospheric transport [higher air-water partitioning coefficients], as well as the potential BTEX contamination from an upstream coal-burning power plant (group 3 in Fig. 1), and the domestic waste discharge from homes may explain the occurrence of BTEX at the upstream sites. BTEX concentrations in samples collected on October 11th and November 8th were not significantly different; hence, measured concentrations were presented as in six samples (Table 1).

To our knowledge, no reports are available on BTEX contamination of surface water in the proximity of hydraulic fracking wells. However, BTEX was found to contaminate groundwater (up to $2000 \mathrm{ppb}$ ) owing to the surface spills of flowback water or fracking fluids in Weld County, Colorado (Gross et al. 2013). BTEX was also found at an average concentration of $8.0-46 \mathrm{ppb}$ in effluent from a wastewater treatment plant that treats wastewater from conventional and fracking wells in Pennsylvania (Ferrar et al. 2013). These studies suggest that flowback water has the potential to contaminate surface water with BTEX. No surface spills related to the hydraulic fracturing activities in Sullivan County, Indiana were reported, to our knowledge, prior to our sampling in the fall of 2015. BTEX were not found in the most downstream site (TCD_F) which may be due to an increased dilution and relatively lower environmental half-lives of BTEX in streams as compared to reservoirs (Table 1).

Calcium and magnesium, the dominant cations in concentration profiles, were found to be higher in sites downstream from the fracking wells, compared to upstream sites (Fig. 3). Sodium was also found at similar concentrations to that of magnesium ions at all downstream sampling sites, whereas sodium ions were found significantly lower (or similar to ammonium ions) in upstream sites. Ammonium and potassium ions were consistently detected at all study sites. Similarly, sulfates and chlorides were the dominant anions in concentration profiles in all sites (Fig. 3). However, fluorides, bromides, nitrites, and nitrates were detected at similar concentrations at all study sites but at significantly lower concentrations (Mann Whitney Rank Sum Test; $p<0.001)$ than sulfates and chlorides.

Fisher (2014) reported very high concentrations of cations $\left(\mathrm{Ca}^{2+}:\right.$ 4300-92,000 ppm; $\left.\mathrm{Mg}^{2+}: 500-21,000 \mathrm{ppm}\right)$ and anions $\left(\mathrm{Cl}^{-}: 8000-190,000 \mathrm{ppm} ; \mathrm{Br}^{-}: 33-850 \mathrm{ppm}\right.$;

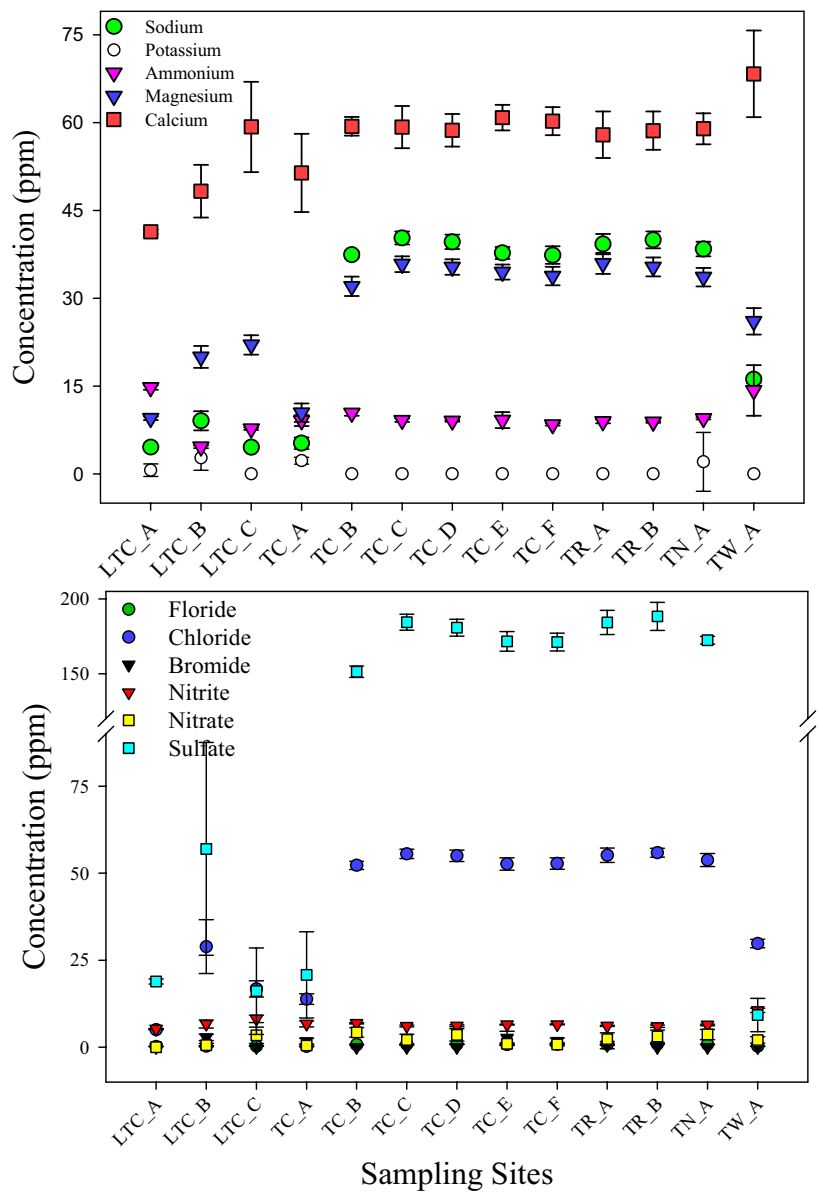

Fig. 3 Concentrations of select cations and anions in study sites

and $\mathrm{SO}_{4}{ }^{2-}: 20-180 \mathrm{ppm}$ ) in flowback water from fracking wells in Texas, California, and North Dakota (Fisher 2014). Surface waters that have been impacted by stray methane gas from coalbed methane hydraulic fracturing have relatively lower calcium, magnesium, and sulfate concentrations, and higher sodium and chloride concentrations (Van Voast 2003), which indicates a potential pathway for flowback water, and consequently other petroleum-hydrocarbons such as BTEX, into surface water. This study found higher concentrations of calcium and magnesium ions at the sites around fracturing wells and different anionic profiles $\left(\mathrm{SO}_{4}{ }^{2-}>\mathrm{Cl}^{-}>\mathrm{NO}_{2}^{-}\right)$than reported by Fisher (2014) $\left(\mathrm{Cl}^{-}>\mathrm{Br}^{-}>\mathrm{SO}_{4}{ }^{2-}\right)$. Therefore, the cation and anionic profiles found in this study could not confirm the contamination of surface water from flowback water in and around the fracturing sites.

A previous study conducted in Sullivan County found sodium $(360 \mathrm{ppm})$ and sulfate $(1100 \mathrm{ppm})$ levels downstream of a surface mining operation to be 18 and 14 fold, respectively, higher than in upstream sites (Peters 1981). Higher levels of sulfates were explained in terms of oxidized products of iron ores during surface coal mining. In 
our study, the sulfate concentration in downstream sites was also found to be eightfold higher than in upstream sites (TC_A and LTC); which may indicate that the operational coal-burning power plant (Fig. 1) increased the sulfate and sodium levels downstream.

Petroleum hydrocarbon-derived contaminants of concern (BTEX) and the dissolved cations and anions were determined in surface water around 15 coalbed methane fracking sites in Sullivan County, IN. At least one BTEX compound was detected in $69 \%$ of sampling sites $(n=13)$ and $23 \%$ of sampling sites were found to be contaminated with all of the BTEX compounds. Overall toluene was the most common BTEX compound detected across all sites, both upstream and downstream. The highest concentration of BTEX was found in two downstream sites and one site upstream from the fracking wells. The upstream presence of BTEX may occur via aerial transport due to the volatile nature of these compounds $\left(K_{\mathrm{H}}>5.39 \times 10^{-3} \mathrm{~atm} . \mathrm{m}^{3} / \mathrm{mole}\right.$ at $\left.25^{\circ} \mathrm{C}\right)$. BTEX was notably absent at the two most downstream sites likely due to the dilution and short environmental half-lives of the compounds. The cationic and anionic profiles determined at our sampling sites $\left(\mathrm{SO}_{4}{ }^{2-}>\mathrm{Cl}^{-}>\mathrm{NO}_{2}^{-}\right)$were not consistent with reported profiles in flowback water from fracking wells in Texas, California, and North Dakota. Furthermore, there is not sufficient evidence to rule out the additional sources of BTEX and dissolved cations and anions (automobile emissions, leaky propane tanks, and geochemical constituents) in addition to the contamination from the fracking operations along Turtle Creek. Therefore, further studies are required to determine the fate and transportation of contaminants from the fracking operations along Turtle Creek, as well as their associated water quality and impacts on human and environmental health.

Acknowledgements The authors would like to acknowledge Laura Demarest of the West Central Indiana Water Alliance for providing GIS data that was utilized to create Fig. 1, and Dr. Frederick Soster of DePauw University for providing feedback regarding the project. We would also like to thank Dr. Jeanette Pope of DePauw University for providing laboratory accessories and access to an ion chromatograph. Funding for this project was provided by the Science Research Fellows program at DePauw University.

\section{References}

Adeyemo OK, Kroll KJ, Denslow ND (2015) Developmental abnormalities and differential expression of genes induced in oil and dispersant exposed Menidia beryllina embryos. Aquat Toxicol 168:60-71

Bolden AL, Kwiatkowski CF, Colborn T (2015) New Look at BTEX: are ambient levels a problem? Environ Sci Technol 49:5261-5276

Carpenter DO (2016) Hydraulic fracturing for natural gas: impact on health and environment. Rev Environ Health 31:47-51

Ferrar KJ, Michanowicz DR, Christen CL, Mulcahy N, Malone SL, Sharma RK (2013) Assessment of effluent contaminants from three facilities discharging Marcellus Shale wastewater to surface waters in Pennsylvania. Environ Sci Technol 47:3472-3481
Finkel ML (2015) The human and environmental impact of fracking. How fracturing shale for gas affects us and our World, ABC-CLIO

Fisher C (2014) Determination of anions and cations in produced water from hydraulic fracturing. http://www.learnpharmascience.com/ tablet-apps/issue12/article3/5_AN71255.pdf. Accessed on December 19th 2016.

Gallegos TJ, Varela BA (2015) United State Geological Survey (USGS) Scintific Investigations Report 2014-5131. Trends in Hydraulic Fracturing Distributions and Treatment Fluids, Additives, Proppants, and Water Volumes Applied to Wells Drilled in the United States from 1947 through 2010 — Data Analysis and Comparison to the Literature. https://pubs.usgs.gov/sir/2014/5131/. Accessed on December 19th 2016

Getzinger GJ, O'Connor MP, Hoelzer K, Drollette BD, Karatum O, Deshusses MA, Ferguson PL, Elsner M, Plata DL (2015) Natural gas residual fluids: sources, endpoints, and organic chemical composition after centralized waste treatment in Pennsylvania. Environ Sci Technol 49:8347-8355

Greenwell K and Keller B (2013) Indiana oil and gas update. http:// heinonline.org/HOL/LandingPage?handle=hein.journals/ twlr19\&div=23\&id=\&page $=$. Accessed on December 19th 2016.

Gregory KB, Vidic RD and Dzombak DA (2011) Water management challenges associated with the production of shale gas by hydraulic fracturing. Elements 7:181-186.

Gross SA, Avens HJ, Banducci AM, Sahmel J, Panko JM, Tvermoes BE (2013) Analysis of BTEX groundwater concentrations from surface spills associated with hydraulic fracturing operations. J Air Waste Manag Assoc 63:424-432

Haluszczak LO, Rose AW, Kump LR (2013) Geochemical evaluation of flowback brine from Marcellus gas wells in Pennsylvania, USA. Appl Geochem 28:55-61

Howarth RW, Ingraffea A, Engelder T (2011) Natural gas: should fracking stop? Nature 477:271-275

Moore TA (2012) Coalbed methane: a review. Int J Coal Geol 101:36-81

Parker KM, Zeng T, Harkness J, Vengosh A, Mitch WA (2014) Enhanced formation of disinfection byproducts in shale gas wastewater-impacted drinking water supplies. Environ Sci Technol 48:11161-11169

Peng C, Lee JW, Sichani HT, Ng JC (2015) Toxic effects of individual and combined effects of BTEX on Euglena gracilis. J Hazard Mater 284:10-18

Perrin J, Cook T (2016) Hydraulically fractured wells provide two-thirds of U.S. natural gas production. http://www.eia.gov/todayinenergy/ detail.php?id=26112. Accessed on December 19th 2016

Peters JG (1981) United States Geological Survey (USGS). Effects of Surface Mining on Water Quality In a Small Watershed, Sullivan County, Indiana. Open File Report 81-543. https://pubs.er.usgs. gov/publication/ofr81543. Accessed on December 19th 2016.

USEPA (2012) United States Environmental Protection Agency (US EPA) National Recommended Water Quality Criteria. http://water. epa.gov/scitech/swguidance/standards/criteria/current/index.cfm. Accessed on December 19th 2016

Van Voast WA (2003) Geochemical signature of formation waters associated with coalbed methane. http://www.mbmg.mtech.edu/pdf/ wayne-cbmgeochem.pdf. Accessed on December 19th 2016

Warner NR, Christie CA, Jackson RB, Vengosh A (2013) Impacts of shale gas wastewater disposal on water quality in western Pennsylvania. Environ Sci Technol 47:11849-11857

Webb E, Bushkin-Bedient S, Cheng A, Kassotis CD, Balise V, Nagel SC (2014) Developmental and reproductive effects of chemicals associated with unconventional oil and natural gas operations. Rev Environ Health 29:307-318 